\title{
K-Means Clustering Video Trending di Youtube Amerika Serikat
}

\author{
Mencari Pola dan Pengelompokkan Video-video Trending
}

\author{
Kevin Widjaja $^{1}$, Raymond Sunardi Oetama ${ }^{2}$ \\ ${ }^{1,2}$ Fakultas Teknologi dan Informasi, Universitas Multimedia Nusantara, Tangerang, Indonesia \\ ${ }^{1}$ kevin.widjaja@student.umn.ac.id \\ ${ }^{2}$ raymond@umn.ac.id
}

Diterima 05 Maret 2020

Disetujui 10 November 2020

\begin{abstract}
Youtube is the most popular video platform in the world today. Successful YouTubers can create videos that are widely viewed by many Youtube users around the world. A lot of viral videos on Youtube came from the United States. But, making viral videos on Youtube is a tough challenge, both for seasoned YouTubers and especially for new YouTubers. This research focuses on discovering the properties of these viral videos by clustering them into distinct clusters. $\mathrm{K}$ Means algorithm is used for the clustering process. The purpose of this clustering process is to look for patterns in the data that were previously unseen. The result shows that the videos are divided into three clusters which are built from 3 variables; views, likes and dislikes. The patterns and insights found in this study can be useful for aspiring video makers who want to achieve success as a Youtuber.
\end{abstract}

Index Terms-clusters, K-Means clustering algorithm, trending video, unsupervised learning, USA, Youtube

\section{PENDAhULUAN}

Per 2019, Youtube adalah sebuah platform berbagi video yang paling populer di dunia. Sebagai portal video terbesar di Internet, YouTube saat ini menguasai $20 \%$ dari lalu lintas di jaringan seluler yaitu sekitar 75, 000 video Youtube ditonton per detik di seluruh dunia [1]. Youtube bukan hanya sekedar sebuah platform berbagi video yang ditujukan untuk hiburan, tetapi platform ini juga berpotensi untuk dijadikan sarana untuk meningkatkan penjualan sebuah perusahaan. Sekitar 54\% pengguna Youtube di Amerika Serikat mengatakan bahwa Youtube penting untuk membantu mereka mengambil keputusan untuk membeli sebuah produk tertentu. Lebih dari 500 jam video diunggah ke Youtube setiap menitnya [2]. Dengan banyaknya video yang diunggah dan ditonton setiap harinya, sulit untuk sebuah video untuk menonjol dan menjadi viral atau trending. Yang dimaksud dengan istilah viral di sini adalah video tersebut sudah dilihat oleh jutaan manusia [3].

Pada penelitian ini akan dibahas tentang pengelompokan video trending di Amerika Serikat dan mengeksplorasi apa saja hal-hal yang mungkin mempengaruhi masing-masing kluster untuk menjadi viral. Bagi beberapa orang, Youtube merupakan tempat untuk mencari uang. Faktor inilah yang menjadi salah satu dorongan untuk membuat video YouTube yang viral. Setiap 1000 views di Youtube dapat menghasilkan sampai dengan 0.5 USD. Pada data set video trending di Amerika Serikat diketahui bahwa rata-rata views adalah 2360785 . Ini berarti satu video viral secara rata-rata dapat menghasilkan sekitar 1200 USD (16.7 juta Rupiah). Selain faktor ekonomi, terdapat juga faktor self-expression yaitu keinginan seseorang untuk mengekspresikan dirinya, yang mendorong seseorang untuk mengunggah video ke platform Youtube. Data diambil dari Youtube Amerika Serikat karena Amerika Serikat memiliki pengguna Youtube terbanyak di dunia dengan 167.4 juta pengguna per November 2018 [4].

Model Clustering dipilih karena lebih pas untuk menggambarkan pengelompokkan karena pengelompokan sifat-sifat video Youtube bukan brrbentuk regresi [5] dan trend yang dibahas bukanlah trend secara analisis numerik stokastik [6]. Video Youtube yang trending ini dikelompokkan dengan metode $k$-means karena metode $k$-means mampu scales to large data sets.

Untuk membuat sebuah video yang viral, perlu dipelajari terlebih dahulu karakteristik video-video yang viral tersebut. Penelitian ini berfokus pada mencari tahu apakah terdapat pola tertentu pada videovideo viral dan apakah terdapat clustering atau pola tertentu dari video-video Trending Youtube di Amerika Serikat. Bila ada, apa saja yang membedakan kluster-kluster ini? Dengan cara apa perbedaanperbedaan ini dapat berguna bagi Youtuber pemula bila mereka mengunggah video ke platform Youtube? Dengan adanya penelitian ini, diharapkan pembaca akan semakin memahami apa saja hal-hal yang mempengaruhi sebuah video agar dapat meraih views, likes, dan comments yang banyak, sehingga dapat membuat video yang trending. Penelitian ini juga akan membantu pembaca yang sekedar ingin 
mencari tahu kemampuan dan contoh penggunaan dari algoritma $K$-Means Clustering.

\section{LANDASAN TEORI}

\section{A. Tentang Algoritma $K$-Means Clustering}

Clustering adalah sebuah proses untuk membagi data menjadi kelompok-kelompok (kluster) berdasarkan sebuah pola tertentu. Clustering bersifat unsupervised learning artinya algoritma ini tidak menerima variabel output untuk dijadikan contoh. Algoritma ini berfungsi untuk mencari pola dari sebuah input tertentu. Berbeda dengan supervised learning yang menerima pasangan input dan output, mempelajari polanya, lalu menggunakannya untuk membuat prediksi.

K-Means Clustering adalah salah satu metode clustering yang paling banyak digunakan, di mana dataset sebanyak " $n$ " dikelompokkan ke dalam grup/kluster sebanyak "k". Tujuan utama dari algoritma K-Means Clustering adalah untuk memperkecil jumlah jarak antara titik-titik dengan masing-masing centroid klusternya. Algoritma yang digunakan dalam K-Means clustering adalah sebagai berikut [7]:

(1) Tentukan titik centroid sebanyak K secara acak,

(2) Atur data sehingga terbentuk K kluster dengan titik-titik centroid yang telah ditentukan sebelumnya. Pengelompokan data dalam Kmeans dilakukan dengan menghitung jarak data dengan titik centroid terdekat. Perhitungan jarak dilakukan dengan jarak Euclidean. Rumus jarak Euclidean secara umum:

$$
d(A, C)=\sqrt{\left(x_{A}-x_{C}\right)^{2}+\left(y_{A}-y_{C}\right)^{2}}
$$

Di mana A adalah data anggota suatu kluster dan $\mathrm{C}$ adalah titik centroid.

(3) Hitung nilai titik centroid dengan menghitung posisi titik tengah dari masing-masing anggota kluster.

(4) Ulangi langkah 2 dan langkah 3 sampai nilai dari titik centroid sudah tidak perubahan.

\section{B. Kelebihan dan Kelemahan Algoritma K-Means Clustering}

Algoritma K-Means Clustering berguna untuk mencari kelompok atau kluster dalam sebuah data yang tidak ditentukan sebelumnya. Algoritma ini dapat bermanfaat untuk mencari tahu pola yang sebelumnya tidak terlihat dari sebuah data. Kelebihan dari KMeans Clustering adalah implementasi yang sederhana, dapat mengolah data yang besar, dan dapat menyesuaikan dengan data yang berbeda-beda. Sedangkan kelemahan dari K-Means Clustering adalah kita harus secara manual menentukan berapa banyak kluster (k) yang mau kita cari sebelum menjalankan algoritmanya. Kualitas hasil algoritma KMeans Clustering juga dapat berkurang bila terdapat outliers sehingga lebih baik untuk mengurangi atau menghapus outliers dari data. Selain itu, k-means juga membutuhkan sumber daya yang besar karena algoritma k-means berulang-ulang kali menyisir data sampai memusat ke satu hasil [5].

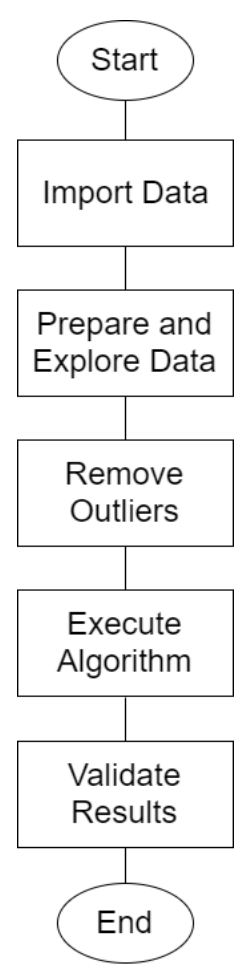

Gambar 1. Flow Chart proses pembuatan model algoritma

\section{Metodologi}

Objek yang diteliti pada penelitian ini adalah video yang viral di Youtube Amerika Serikat. Video-video yang diteliti memiliki atribut antara lain berapa kali video tersebut ditonton (views), berapa banyak orang yang menyukai video tersebut (likes), dan berapa banyak orang yang tidak menyukai video tersebut (dislike). Sebagaimana terlihat pada Gambar 1, kerangka kerja dari penelitian ini terdiri dari import data, prepare and explore data, remove outliers, execute algorithm, dan validate results.

\section{A. Proses 1: Import Data}

Data set yang digunakan pada penelitian ini adalah data set "Trending YouTube Video Statistics" yang diunduh dalam bentuk file .csv dari Kaggle.com. Karena keterbatasan perangkat keras, dari data yang disediakan, hanya 500 observasi dari data Amerika Serikat yang digunakan untuk perhitungan k-means 
clustering. Bentuk data yang digunakan berupa tabel dengan 16 kolom (variabel). Dari ke 16 kolom ini, yang digunakan untuk algoritma clustering hanya kolom 8, 9, dan 10 (views, likes, dan dislikes) yang semuanya merupakan variabel numerik. Kolom-kolom lain tidak digunakan karena tidak relevan dan tipe datanya tidak sesuai untuk proses k-means clustering. Data yang digunakan pada penelitian ini valid karena data dikumpulkan menggunakan YouTube Data API oleh seorang pengguna Kaggle bernama Mitchell J. Untuk setiap video yang terdapat di dataset dilakukan pencarian di Google, dan terbukti video tersebut sungguh ada dan bukan video palsu [8].

\section{B. Proses 2: Prepare and Explore Data}

Proses ini menerima input berupa data yang sudah diimpor ke dalam RStudio. Dari kolom yang terdapat pada data, hanya 3 yang akan digunakan untuk clustering yaitu views, likes, dan dislikes. Pada proses ini, sebuah dataset baru dibuat dari data video YouTube yaitu myData yang menampung hanya ketiga kolom yang dibutuhkan untuk menjalankan algoritma. Mean, median, min, max, dan kuartil dihitung dengan fungsi summary pada RStudio. Lalu, untuk memvisualisasikan data, digunakan boxplot untuk melihat persebaran data. Uji Normalitas Anderson-Darling digunakan untuk menguji normalitas dari variabel-variabel views, likes, dan dislikes.

\section{Proses 3: Remove Outliers}

Outliers adalah pengamatan yang terletak pada jarak yang tidak normal dari nilai-nilai lain dalam sampel acak dari suatu populasi. Pada penelitian ini, kami menggunakan box plot untuk mendeteksi outliers. Box plot dibuat dengan menggambar kotak di antara kuartil atas dan bawah dengan garis solid yang ditarik melintasi kotak untuk menandakan median. Untuk mengidentifikasi outliers, kita harus menghitung fence seperti berikut:

$$
\begin{aligned}
& \text { lower inner fence }=Q 1-1.5 * I Q \\
& \text { upper inner fence }=Q 3+1.5 * I Q
\end{aligned}
$$

di mana: Q1 adalah kuartil 1, Q3 adalah kuartil 3, dan IQ adalah jarak antar kuartil (Interquartile range) yaitu Q3-Q1. Nilai-nilai yang berada "di luar" fence tersebut dikategorikan sebagai sebuah pencilan (outlier). "Di luar" di sini maksudnya adalah lebih kecil daripada lower inner fence atau lebih besar daripada upper inner fence [9].

Karena sifat mean yang sangat mudah terpengaruh dengan nilai yang ekstrem seperti pencilan, algoritma K-means Clustering juga sangat sensitif terhadap outliers, sehingga pada penelitian ini outliers dari myData dihapus. Proses menerima input berupa myData dari proses sebelumnya, lalu menggunakan fungsi for untuk berulang-ulang menghapus outliers sampai tidak ada outliers lagi. Outlier adalah datadata yang berada di luar range dari batas bawah dan batas atas. Proses remove data outliers dilakukan dengan menggunakan program $\mathrm{R}$ [10].

\section{Proses 4: Execute Algorithm}

Pada proses ini, input diterima berupa myData yang sudah bersih dari outliers. Dikarenakan keterbatasan kekuatan komputasi, data yang diambil hanya sebanyak 500 observasi yang dipilih secara random sampling, sehingga ukuran myData menjadi sebanyak 500 observasi. Setelah mengurangi jumlah observasi, myData digunakan untuk membuat model k-means clustering menggunakan fungsi kmeans() pada RStudio. $\mathrm{K}$ dimulai dengan nilai 1 sampai dengan 10 kemudian nilai $\mathrm{K}$ dipilih dengan menggunakan elbow method. Elbow Method merupakan metode yang bersifat visual. Ide dari elbow method adalah meningkatkan k sebanyak 1 setiap kali, lalu hitung within sum of squares (wss) masingmasing k. Pada satu titik, nilai wss turun secara dramatis, lalu menjadi mendatar. $\mathrm{K}$ pada titik inilah yang paling optimal untuk dijadikan jumlah kluster [11].

\section{E. Proses 5: Validate Results}

Proses ini menerima input berupa model yang dihasilkan oleh algoritma. Pada proses ini, hasil kluster yang sudah dibuat oleh algoritma akan diuji kualitasnya. Proses akan menghasilkan nilai tertentu yang menentukan kualitas dari model. Terdapat 2 jenis clustering validation statistics, yaitu Internal kluster validation dan External kluster validation. Internal cluster validation menggunakan informasi internal untuk mengevaluasi kluster, sedangkan external cluster validation, membandingkan hasil analisis kluster dengan hasil yang diketahui secara eksternal, seperti label kelas yang disediakan dari luar data yang digunakan. External cluster validation mengukur sejauh mana label dari klaster cocok dengan label kelas yang disediakan secara eksternal. Karena kita sudah tahu kluster yang "benar" sebelumnya, external cluster validation lebih sering digunakan untuk menilai dan memilih algoritma pengelompokan yang tepat untuk sebuah set data tertentu, daripada untuk menilai kinerja algoritma pada data yang belum terkelompokkan sebelumnya. Sehingga pada penelitian ini, kluster validation yang digunakan hanya Internal kluster validation karena tidak terdapat label eksternal yang diketahui untuk dijadikan acuan pada external cluster validation. Fungsi yang digunakan adalah cluster.stats dari library fpc pada RStudio [12].

Metode pertama yang akan digunakan untuk validasi hasil adalah menguji Dunn Index. Dunn Index adalah perbandingan jarak terkecil antara pengamatan yang tidak berada dalam kluster yang sama dengan jarak terbesar antar 2 titik di dalam kluster yang sama. Indeks Dunn memiliki nilai antara nol dan infinity. 
Semakin tinggi nilai Dunn Index, maka semakin baik klusternya. Nilai Dunn index didapatkan dengan menjalankan perintah pada RStudio yaitu stat\$dunn. Formula Dunn Index adalah:

$$
D I=\frac{\min \delta\left(C_{i}, C_{j}\right)}{\max \Delta k}
$$

di mana: $\delta\left(C_{i}, C_{j}\right)$ adalah jarak antar kluster Ci dengan kluster $\mathrm{Cj}$, dan max $\Delta k$ adalah jarak di dalam kluster $\mathrm{k}$, atau bisa dibilang metrik untuk mengukur besar kecilnya kluster. Nilai DI yang semakin tinggi mengindikasikan jarak antar kluster yang semakin besar (kluster terpisah jauh satu sama lain) dan jarak di dalam kluster yang semakin kecil (ukuran kluster yang lebih kecil) [13].

Metode kedua yang akan digunakan untuk validasi hasil adalah memeriksa Average-Between dan Average-Within dari kluster. Average-Between adalah rata-rata jarak antar kluster. Semakin besar nilai Average-Between maka antara kluster semakin terpisah jauh dan model kluster semakin baik. Average-Within adalah rata-rata jarak antar titik di 1 kluster yang sama. Semakin kecil Average-Within maka anggota kluster akan semakin mendekati pusat kluster, dan model kluster semakin baik. Average Between didapatkan dengan menjalankan perintah stat\$average.between pada RStudio. Average within didapatkan dengan menjalankan perintah stat\$average.within pada RStudio [12].

Metode ketiga yang akan digunakan untuk memvalidasi hasil adalah membuat silhouette plot dengan pertama-tama menghitung silhouette coefficient (Si) terlebih dahulu.

Silhouette coefficient dihitung dengan menggunakan rumus sebagai berikut:

$$
S i=\frac{(b-a)}{\max (a, b)}
$$

di mana a adalah rata-rata jarak intra-kluster (mean intra-cluster distance), dan $\mathrm{b}$ adalah rata-rata jarak terdekat antar kluster (mean nearest-cluster distance). Dengan kata lain, b adalah jarak antara sebuah sampel dan kluster terdekat yang bukan kluster sampel tersebut. Nilai Si berkisar antara -1 sampai 1. Semakin nilai Si mendekati 1 maka titik-titik di dalam kluster semakin mirip, berarti data terkelompokkan dengan baik. Sebaliknya, semakin nilai Si mendekati -1 maka titik-titik di kluster semakin berbeda, dan data tidak terkelompokkan dengan baik. Silhouette didapatkan dengan menjalankan perintah silhouette() pada RStudio [14].

\section{HASIL DAN PEMBAHASAN}

\section{A. Proses 1: Import Data}

Sebagaimana terlihat pada Gambar 2, output dari proses 1 adalah sebuah data frame yang dapat digunakan di RStudio. Data frame ini sangat besar dan berisi 16 variabel yang berbeda. Library yang digunakan untuk mengimpor data adalah library reader. Data frame disimpan dalam variabel data.

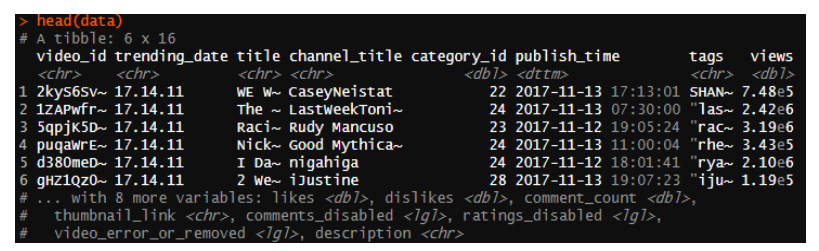

Gambar 2. Head dari data

\section{B. Proses 2: Prepare and Explore Data}

Sebagaimana terlihat pada Gambar 3, output proses 2 adalah data yang lebih ringkas yang hanya terdiri dari 3 variabel, ciri-ciri data, dan boxplot dari

\begin{tabular}{|c|c|c|c|c|c|}
\hline \multicolumn{2}{|c|}{$\begin{array}{l}\text { summary (mybata) } \\
\text { vi ews }\end{array}$} & \multicolumn{2}{|c|}{ likes } & \multicolumn{2}{|c|}{ dislikes } \\
\hline Min. & 549 & Min. & 0 & Min. & : \\
\hline 1st Qu. & 242329 & 1st Qu. : & 5424 & 1st Qu. & 202 \\
\hline Median & 681861 & Median : & 18091 & Median & 631 \\
\hline Mean & 2360785 & Mean & 74267 & Mean & 3711 \\
\hline 3rd Qu. & 1823157 & 3rd Qu. : & 55417 & 3rd Qu. & 1938 \\
\hline Max. & :225211923 & Max. & :5613827 & Max. & $: 1674420$ \\
\hline
\end{tabular}
data.

Gambar 3. Summary dari ketiga variabel yang diteliti

Karena data yang diterima dari Kaggle.com ini sudah bersih, maka tidak perlu dilakukan cleansing, namun perlu dilakukan penghapusan outliers yang akan dijelaskan pada bagian berikut.

\section{Proses 3: Remove Outliers}

Output proses 3 adalah data yang sudah bersih dari outliers, jumlah data berkurang dari 40949 menjadi 22930.

Cara menghapus outliers adalah dengan menggunakan for loop pada Rstudio. Berikut adalah penjabaran langkah-langkahnya:

1. Buat boxplot menggunakan data, dan cari outliers-nya,

2. Bila ada outliers, maka hapus outliers yang ada di boxplot tersebut lalu ulangi langkah 1 dengan data yang sudah dikurangi outliersnya.

3. Bila tidak ada outliers maka loop selesai.

Aktivitas ini diulang-ulang sampai outliers sepenuhnya hilang dari data. Gambar 6 memperlihatkan hasil sebelum dan setelah outliers dihilangkan. 


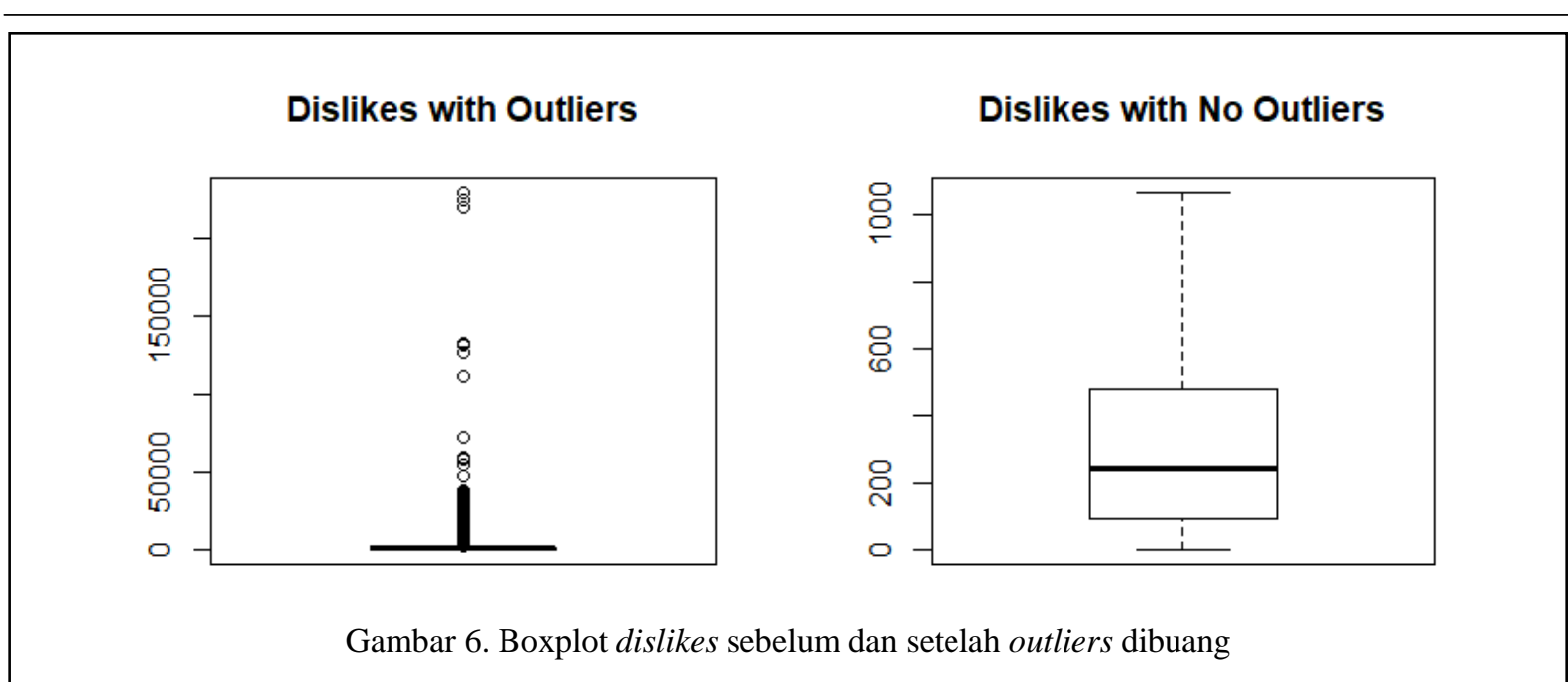

\section{Proses 4: Execute Algorithm}

Output proses 4 adalah hasil k-means clustering dari data yang sudah dibuang outliersnya. Jumlah sampel yang digunakan untuk penelitian dikurangi dengan metode random sampling sebanyak 500 observasi. Hasilnya dapat dilihat pada Gambar 4.

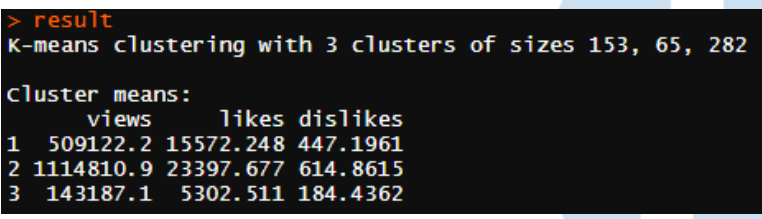

Gambar 4. Hasil clustering

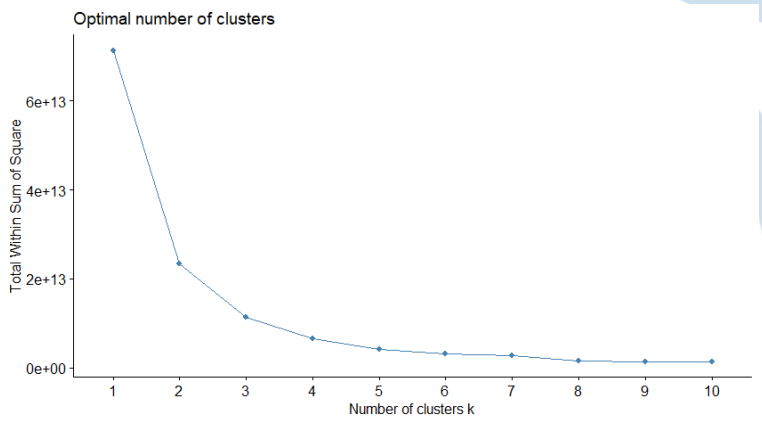

Gambar 5. Grafik untuk mengidentifikasi elbow point

Dari Gambar 5, terlihat penurunan dari $\mathrm{k}=2 \mathrm{ke} \mathrm{k}$ $=3$, lalu pelandaian mulai dari $\mathrm{k}=3$ sampai $\mathrm{k}=4$ dan seterusnya. Sehingga dari grafik tersebut kita dapat $\mathrm{k}$ yang paling optimal yaitu $k=3$. Sehingga nilai $k=3$ dipilih untuk penelitian ini.

\section{E. Proses 5: Validate Results}

Output proses 5 adalah hasil validasi algoritma dan informasi mengenai kualitas clustering hasil algoritma k-means clustering. Hasilnya terlihat pada Gambar 7.

Validasi hasil metode 1 menggunakan Dunn Index. Clustering yang dibuat memiliki Dunn Index sebesar
0.004403429. Hasil ini menandakan kluster hasil algoritma kurang baik karena hasil ini menunjukkan bahwa jarak terbesar 2 titik intra-kluster jauh lebih besar daripada jarak terkecil 2 titik beda kluster. Hal ini dapat dipahami sebagai kluster-kluster yang berdempetan, tidak berjarak jauh satu sama lain, dan kluster-kluster yang cenderung "lebar".

Validasi hasil metode 2 menggunakan AverageWithin dan Average-Between. Clustering yang dibuat memiliki Average-Between sebesar 555105.1. Nilai ini cukup besar, sehingga diketahui bahwa jarak antar kluster cukup jauh. Sedangkan nilai Average-Within dari clustering ini adalah 145126.5. Nilai ini cukup kecil, sehingga diketahui bahwa titik-titik cenderung berkumpul ke arah pusat klusternya.

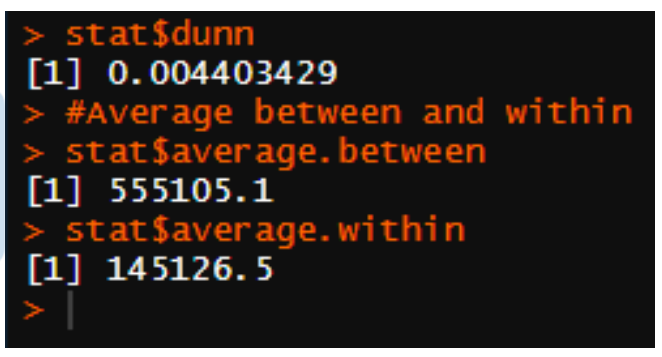

Gambar 7. Hasil kalkulasi Dunn Index, AverageBetween dan Average-Within

Validasi hasil metode 3 menghitung Silhouette Coefficient dan membuat Silhouette Diagram. Setelah dikalkulasi oleh RStudio, didapat hasil Silhouette coefficient per kluster. Terlihat bahwa kluster 1 memiliki silhouette coefficient 0.51 , kluster 2 memiliki silhouette coefficient 0.54, dan kluster 3 memiliki silhouette coefficient 0.64 . Hal ini berarti kluster 1,2, dan 3 sudah terkelompokkan dengan cukup baik. Dari silhouette diagram terlihat bahwa rata-rata silhouette coefficient juga cukup baik, yaitu 0.59. Hal ini berarti clustering yang terbentuk cukup baik. Hasilnya terlihat pada Gambar 8. 


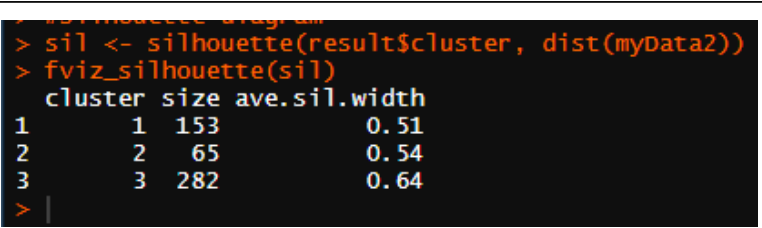

Gambar 8. Hasil kalkulasi silhouette coefficient

\section{F. Diskusi}

Sebagaimana terlihat pada Gambar 9, hasil clustering dari algoritma tersebut membagi data menjadi 3 kluster. Kluster pertama memiliki anggota sebanyak 153 titik dari total 500 titik. Kluster ini memiliki ciri-ciri views, likes, dan dislikes berada di tengah-tengah 2 kluster lainnya. Terdapat 34.82 likes setiap 1 dislikes artinya secara keseluruhan video ini cukup disukai oleh penonton, walaupun jumlah views jauh di bawah kluster kedua, jumlah views hanya sekitar setengah dari kluster kedua.

Kluster kedua memiliki anggota paling sedikit yaitu hanya 65 dari 500 video. Sebagaimana terlihat pada gambar 10, gambar 11, dan gambar 12, kluster ini memiliki jumlah views, likes, dan dislikes terbanyak dari antara kluster lainnya, dan memiliki jumlah likes terbanyak setiap 1 dislikes, walaupun berbeda tipis dengan kluster pertama. Ini menunjukkan bahwa video pada kluster ini secara umum yang paling disukai, dan paling populer dari antara ketiga kluster lainnya. Tetapi, kluster ini adalah yang paling sulit dicapai, tercermin dari anggotanya yang paling sedikit dari antara kedua kluster lainnya.

Kluster ketiga memiliki jumlah views, likes, dan dislikes yang paling sedikit dari antara kluster lainnya. Rata-rata views pada kluster ini hanya $10 \%$ dari ratarata views pada kluster kedua. Jumlah likes setiap 1 dislikes juga paling kecil, artinya dibanding dengan kedua kluster lainnya, video pada kluster ini secara umum paling tidak disukai. Namun sebagaimana terlihat pada gambar 13, anggota pada kluster ini paling banyak yaitu 282 video, yang berarti sebagian besar video masuk pada kluster ini.

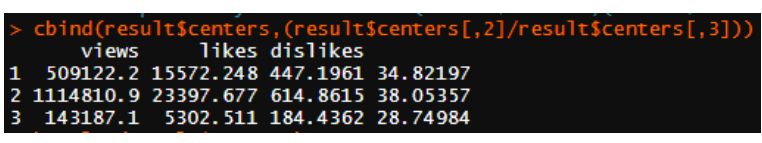

Gambar 9. Menghitung jumlah likes setiap 1 dislikes

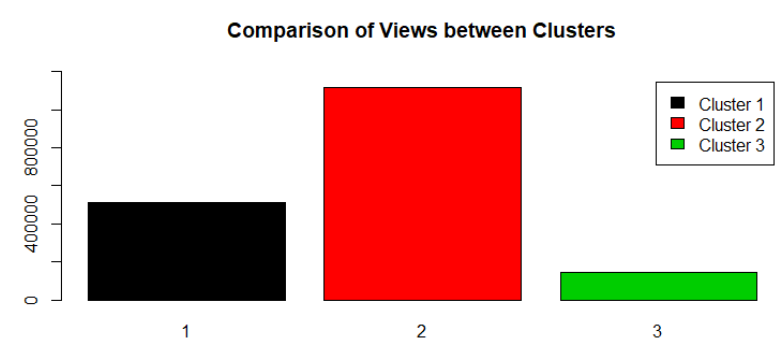

Gambar 10. Perbandingan rata-rata views antar kluster

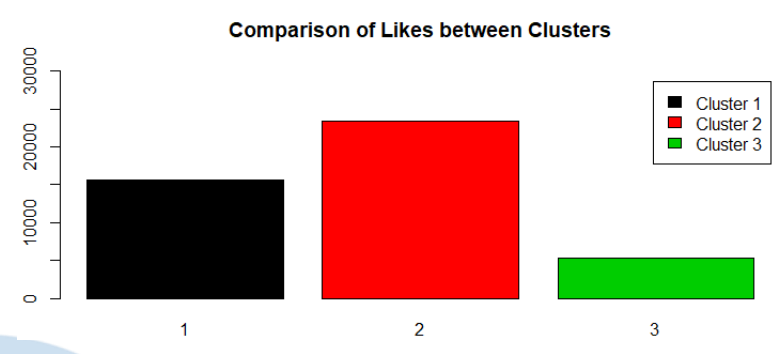

Gambar 11. Perbandingan rata-rata likes antar kluster

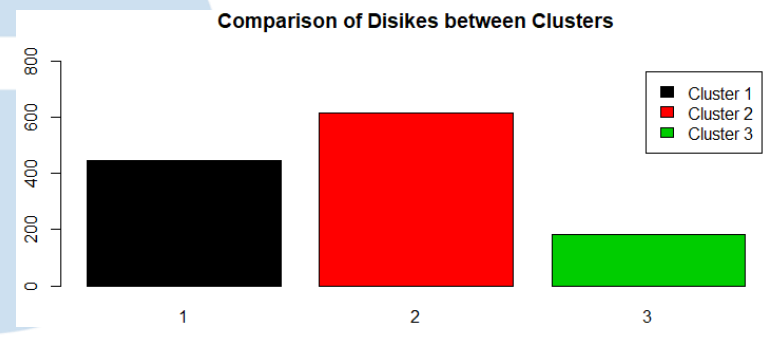

Gambar 12. Perbandingan rata-rata Dislikes antar kluster

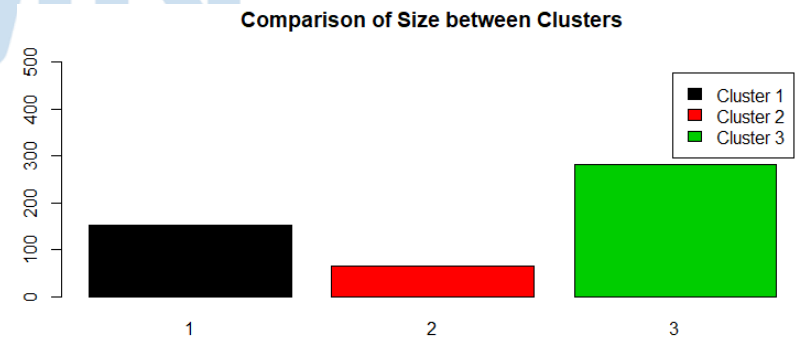

Gambar 13. Perbandingan ukuran ketiga kluster

\section{SIMPULAN}

\section{A. Kesimpulan}

Penelitian ini memberi informasi tentang pengelompokan video trending di YouTube Amerika Serikat. Diketahui bahwa terdapat 3 kluster dengan ciri-cirinya masing-masing. Kluster dengan views, likes, dan dislikes paling sedikit adalah kluster dengan anggota terbanyak, sedangkan kluster dengan views, likes, dan dislikes terbanyak memiliki anggota paling 
sedikit. Semakin populer sebuah video, maka cenderung semakin disukai oleh banyak orang.

Untuk membuat video yang viral, tidak cukup hanya membuat video saja, tetapi pembuat video juga harus paham dengan kondisi video-video di platform YouTube. Mereka harus menargetkan videonya agar berada di puncak, dalam konteks penelitian ini berarti masuk ke kluster kedua. Pembuat video yang hendak mengunggah videonya ke YouTube dapat melihat bahwa ada pola di dalam video-video trending. Dari hasil clustering terlihat bahwa kluster kedua adalah kluster dengan anggota yang paling "sukses" dan di saat yang sama adalah kluster yang paling sedikit anggotanya.

\section{B. Saran}

Algoritma K-Means Clustering juga membutuhkan peneliti untuk menentukan $\mathrm{k}$ atau jumlah kluster sebelum menjalankan algoritmanya. Untuk menentukan jumlah kluster, peneliti harus mengandalkan grafik dan melihat secara subjektif. Algoritma lain seperti hierarchial clustering dapat menentukan kluster tanpa peneliti menentukannya terlebih dahulu.

\section{Limitasi}

Limitasi dari penelitian ini adalah jumlah kluster harus ditentukan terlebih dahulu oleh peneliti, dan tidak terdapat metode yang objektif untuk mencari tahu jumlah kluster yang optimal untuk k-means clustering.

Keterbatasan lain pada penelitian ini adalah outliers sepenuhnya dihapus. Dengan dihapusnya outliers, ada kemungkinan yang besar terdapat informasi penting yang hilang bersama dengan outliersnya. Penelitian selanjutnya mungkin dapat menggunakan algoritma yang tidak terganggu oleh outliers.

\section{UCAPAN TERIMA KASIH}

Penelitian ini didukung oleh pendanaan dari Universitas Multimedia Nusantara, Tangerang, Indonesia.

\section{DAFTAR PUSTAKA}

[1] Schwind, Anika, M. Cise, A. Özgü, G. Carste, and W. Florian. "Dissecting the performance of YouTube video streaming in mobile networks." International Journal of Network Management, vol.30, no. 3, 2020.

[2] A. Smith, S. Toor dan P. V. Kessel, "Many Turn to YouTube for Children's Content, News, How-To Lessons," Pew Research Center Internet \& Technology, 7 November 2018.

[3] Lexico, "Viral," Lexico Powered by Oxford, 2020. [Online]. Available: https://www.lexico.com/definition/viral. [Diakses 17 May 2020].

[4] J. Clement, "Hours of video uploaded to YouTube every minute as of May 2019," Statista, 9 August 2019.
[5] Merfin dan R. S. Oetama, "Prediksi Harga Saham Perusahaan Perbankan Menggunakan Regresi Linear Studi Kasus Bank BCA Tahun 2015-2017", ULTIMATICS. Vol. 11, No. 1, 2019:

[6] R. S. Oetama, "Analisis Titik Tertinggi dan Terendah dengan Model Stokastik pada Perdagangan Mata Uang Modern: Studi Kasus Perdagangan Harga Emas Bulan April - September 2016", ULTIMA INFOSYS, Vol.7 No. 2, 2016.

[7] I. E. A. Parlina, "Memanfaatkan Algoritma K-Means dalam Menentukan Pegawai yang Layak Mengikuti Assessment Center untuk Clustering Program SDP," Computer Engineering, Science and System Journal, vol. 3, no. 1, hal 87-93, 2018.

[8] Michele. J, "Trending YouTube Video Statistics," 3 June 2019. [Online].

[9] NIST/SEMATECH, e-Handbook of Statistical Methods, 2013

[10] U. C. Academy, "Removing outliers - quick \& dirty," RPubs by RStudio, 2018 .

[11] Nainggolan, Rena, Resianta Perangin-angin, Emma Simarmata, and Astuti Feriani Tarigan. "Improved the Performance of the K-Means Cluster Using the Sum of Squared Error (SSE) optimized by using the Elbow Method." In Journal of Physics: Conference Series, vol. 1361, no. 1, p. 012015. IOP Publishing, 2019.

[12] Nerurkar, Pranav, Aruna Pavate, Mansi Shah, and Samuel Jacob. "Performance of internal cluster validations measures for evolutionary clustering." In Computing, Communication and Signal Processing, hal. 305-312. Springer, Singapore, 2019

[13] Jin X., Han J. “K-Medoids Clustering”. In: Sammut C., Webb G.I. (eds) Encyclopedia of Machine Learning. Springer, Boston, MA, 2019.

[14] Dinh, D. Tai, T. Fujinami, and V. N. Huynh. "Estimating the Optimal Number of Clusters in Categorical Data Clustering by Silhouette Coefficient." In International Symposium on Knowledge and Systems Sciences, hal. 1-17. Springer, Singapore, 2019. 